\title{
To Mitigate The Agency Risk In Offshore Outsourcing Through The Transfer Of Personnel
}

\author{
${ }^{1}$ Florence Duvivier, ${ }^{2}$ Carine Peeters \\ ${ }^{1}$ NEOMA Business School, France \\ ${ }^{2}$ Vlerick Business School, Belgium
}

\begin{abstract}
.
We study how the exchange of personnel between clients and offshore providers contributes to effective relational governance of offshore outsourcing. More specifically, the paper elucidates the associated mechanisms that explain how the exchange of personnel help reduce agency risk, and synthesize them in an integrative framework. Further the qualitative study shows the reasons bi-directional exchange of personnel takes place, and show how their actions differs in function of the direction of the transfer. Based on that insight, we identify three main mechanisms whereby expatriation helps reduce agency risk in offshore outsourcing - namely i) via a reduction in the information asymmetry between clients and offshore providers, ii) via the increased motivation of offshore teams to comply with clients' expectations, and iii) via the empowered trust between clients and offshore providers. The study also points to a number of possible drawbacks client firms must account for when planning to send expatriates to offshore providers, and which further explains that the reverse process of welcoming expatriates from offshore providers into the client organization holds significant potential to offshore outsourcing relations.
\end{abstract}

Keywords: Offshore outsourcing, Expatriate, Agency risk 


\section{Introduction}

By outsourcing technical and business services activities (e.g. information technology services, administrative functions, call centers, engineering services) offshore, firms enjoy greater access to skills and qualified personnel (Lewin, Massini, \& Peeters, 2009), opportunities to learn (Jensen, 2009), and other cost and resources advantages (Lewin \& Peeters, 2006). These benefits lead managers to consider outsourcing activities across an increasingly diverse set of host countries and functional domains (Jensen \& Pedersen, 2011) to the point of 'slicing' value chains (Contractor, Kumar, Kundu \& Pedersen, 2010) to locate every process, or bundle of processes, where it is best suited strategically, organizationally and financially. But offshore outsourcing also involves risks - for instance to the intellectual property of client firms (e.g. Gooris \& Peeters, 2016), or risk that the work performed by the offshore provider does not meet client's expectations (e.g. Stringfellow, Teagarden \& Nie, 2008; Hutzschenreuter, Lewin \& Dresel, 2011). Underlying those risks is the well-known agency problem in interorganizational exchanges (e.g. Poppo \& Zenger, 2002), whereby, due to information asymmetry and diverging interests, agents may not behave in the principal's best interest (see, e.g., Eisenhardt, 1989).

Extant research on agency risk in outsourcing suggests that relying on the contract alone is not sufficient to fulfill clients' need for control (Koh, Ang \& Shaub, 2004; Huber, Fischer, Dibbern \& Hirschheim, 2013; Li, Xie, Teo \& Peng, 2010). Moreover, the distance between client firms and their offshore providers (e.g. Gooris \& Peeters, 2014; Kshetri, 2007) makes agency problems in offshore outsourcing even more acute than in domestic outsourcing relations (e.g. Dibbern, Winkler \& Heinzl, 2008; Sidhu \& Volberda, 2011). Cultural and language differences increase the risk of miscommunication and misunderstandings (Ang \& Inkpen, 2008; Peeters, Dehon \& Garcia-Prieto, 2015), and are often aggravated by status differences between the client and offshore teams (Levina \& Vaast, 2008). The geographic distance and time zone differences make it more difficult for the teams to interact and coordinate (Kumar, Van Fenema \& Von Glinow, 2009; Stringfellow et al., 2008). But despite the problem not being new, and particularly acute in the context of offshore outsourcing, few studies (see Manning et al., 2011, for a notable exception) help shed light on how clients can mitigate agency risk by appropriately managing offshore outsourcing relations.

Given the international nature of offshore outsourcing, agency problems share a number of similarities with those observed between headquarters and foreign subsidiaries of MNCs (e.g. Roth \& O' Donnell, 1996; Björkman, Barner-Rasmussen, \& Li, 2004). At the same time, offshore outsourcing and HQ-subsidiary relations differ in many ways - none the least in the fact that client company teams have no formal hierarchical power on the offshore provider's teams, and offshore providers may be reluctant to welcome in their premises managers from the client (Manning et al., 2011). On this background, we study how the exchange of personnel between clients and their offshore providers can help clients manage their offshore outsourcing activities. 


\section{MANAGEMENT AND ECONOMICS}

Our qualitative study is based on insight gained on offshore outsourcing relations initiated by 32 companies located in Belgium and outsourcing service activities to a variety of foreign countries. The interview data we collected give rich evidence on how the transfer of personnel both from the client and from the provider help reduce agency risk by fostering alignment of offshore providers' behavior with the clients' best interest.

Although past research has already pointed to the critical role that relational governance plays in controlling interorganizational exchanges (e.g. Poppo \& Zenger, 2002), including offshore outsourcing relations (Manning et al., 2011), this study is the first to explicitly conceptualize relational governance via the transfer of personnel between clients and offshore providers. Specifically, the main contribution of this paper to extant literature on offshore outsourcing is to elucidate the associated mechanisms that explain how the transfer of personnel help reduce agency risk, and to synthesize them in an integrative framework. In addition, this study responds to recent calls in the expatriation literature to investigate the bi-directional transfer of personnel simultaneously, such as to be able to compare their actions (Harzing, Pudelko \& Reiche, 2016). Moreover, despite the large recognition that expatriates are send for various purposes such as transferring knowledge and exert control, to date there is little empirical knowledge on the processes they use to fulfil these roles. We therefore focus on the why bidirectional exchange of personnel takes place, and show how their actions differs in function of the direction of the transfer. Further, this research points to a number of drawbacks of sending expatriates from the client to the offshore provider, which help explain why sending expatriates from the offshore provider to the client become increasingly common and effective. Finally, in contrast to HQ-subsidiary relations, the outsourcing context of our study allows extending current knowledge of how expatriates may help firms mitigate the agency risks when there is no formal hierarchical relation between the international parties involved in a relation.

\section{Methodology}

We studied 32 offshore outsourcing initiatives by 32 client companies located in Belgium, focusing on understanding how clients came to rely on expatriates - both sent to the offshore providers and welcomed from the offshore providers -, and how expatriates from and to the client can help alleviate potential agency problems in a client-offshore provider relationship.

We conducted interviews solely in client organizations that outsource business services activities to external offshore providers located in foreign countries. We used an interview guide to ensure that we asked the same questions in each interview. We did not structure the interviews around academic theories and terminologies to avoid, as far as possible, imposing theoretical constructs on the respondents. We thus aimed to avoid the danger of misrepresentation by the interviewer (Hancox \& Hackney, 2000). The interview guide comprised three parts. The first dealt with questions on the drivers and location of offshore outsourcing arrangements. The second part asked participants to describe the problems (e.g. risk, conflict, misunderstanding...) their company had encountered in a particular offshore outsourcing initiative, and how these difficulties were managed. In the third part, respondents explained i) their decision to use (or not use) expatriates from and/or to the client, ii) the 


\section{MANAGEMENT AND ECONOMICS}

respective roles of expatriates, and iii) how these roles were carried out in practice. The interview questions were deliberately open-ended to allow participants to share their experience on the topic fully. To accommodate the participants, we kept the order of the questions flexible and added some to follow up on previous points. Interviews were as informal as possible to encourage spontaneous statements and sharing of insight. To maintain consistency, the first author handled all the interviews. The interviewer promised that the name of the firms and of the interviewees would remain confidential. We carried out the interviews face-to-face, with the exception of two that were held on the phone. The interviews were conducted in English, as the interviewees had a good command of English and were used to international communication (Welch, Marschan-Piekkari, Penttinen, \& Tahavanainen, 2002). The interviews lasted between 40 and $100 \mathrm{~min}$. All the interviews were recorded and transcribed.

We contacted executives from 79 companies in Belgium that had already participated in a previous research project and which we knew were involved in at least one offshore outsourcing relation. Executives from 32 of the 79 companies expressed interest in the project and were willing to participate. For the interviews, we sought respondents who met three main criteria: i) the company offshored services via an external service offshore provider; ii) the respondent held a managerial position in the company; and iii) the respondent had first-hand knowledge of service offshoring initiatives by the company. We decided to target executives and senior managers as they would most likely be able to answer the full range of questions or direct us to the most appropriate person in the company, and they had authority to assign expatriates abroad.

Respondents are either executives $(53 \%)$ or managers $(47 \%)$. 94\% are male. The sample contains firms in a variety of sectors: technology (32\%), consumer non-cyclical (16\%), industrial (16\%), financial and insurance services (12\%), and others (24\%). It consists mainly of large firms $(81 \%)$ and a large proportion of the offshore outsourcing initiatives are located in India (63\%), especially in IT and Software development. This is not surprising since previous research has shown that India has a large pool of IT and software professionals with lower salaries than in developed countries (Joshi \& Mudigonda, 2008).

The analysis of interview data proceeded in two main phases. First, we identified all excerpts of the interview transcripts that provided information relevant to our main questions - that is why do clients come to transfer personnel to or from their offshore providers, and how do the expatriates help clients mitigate agency risks. And we categorized the excerpts in function of the direction of the transfer of personnel: category 1 for information related to personnel transferred from the client to the offshore provider, and category 2 for information related to personnel transferred from the offshore provider to the client.

\section{Findings}

The framework shown in Figure 1 integrates the expatriate from and to the client that can lead to mitigate the information asymmetry that exist in an offshore provider relationship, to increase the offshore members' motivations to comply their day-to-day tasks and to empowered trust between clients and offshore providers, and in turn reduce the agency 


\section{MANAGEMENT AND ECONOMICS}

problems. We highlight the mechanisms from the client to mitigate the agency risks in offshore outsourcing through the transfer of personnel both from and to the client. We also point a number of possible drawbacks client firms must account for when planning to send expatriates to offshore providers. All the aspects of our integrative framework are described in the following section (see Figure 1).

Figure 1: Integrative framework

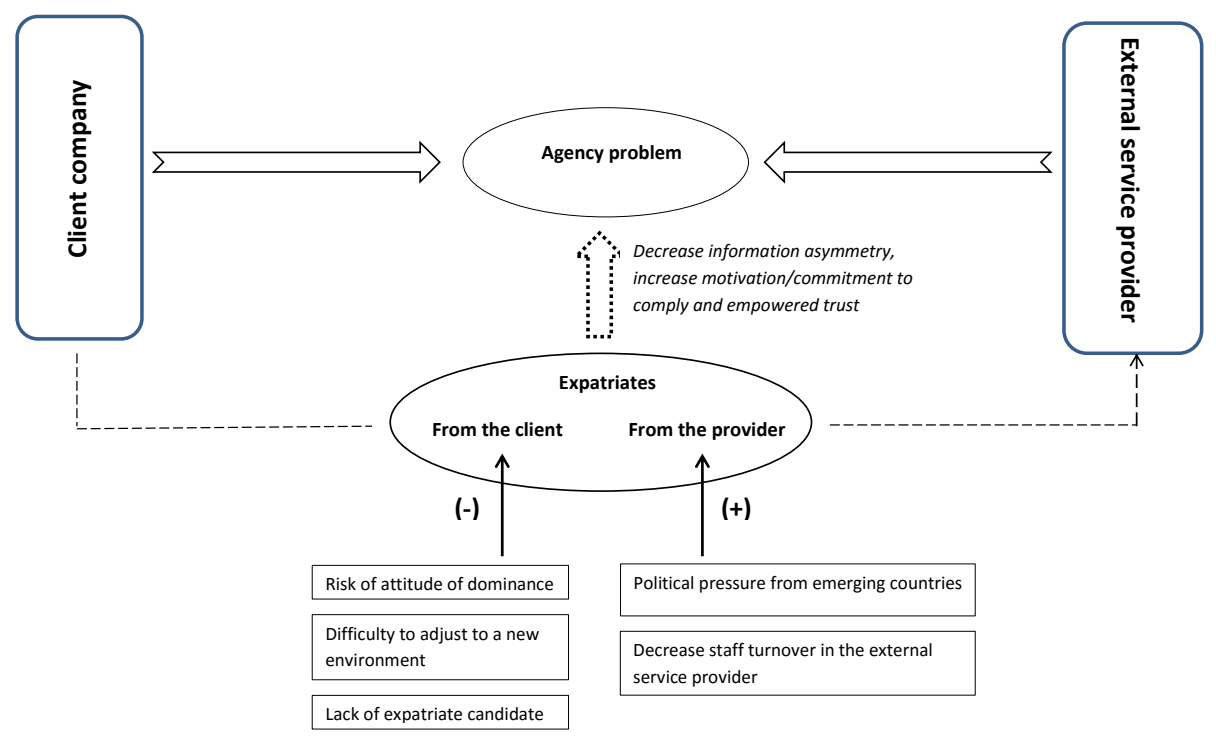

First we show that expatriates sent from the client to the provider help formally control that the provider executes the allotted tasks in line with the overall interest of the client company. We observe that they exert formal control over offshore outsourcing activities through progress review meetings, the identification of problems, and simply direct observation to ensure that offshore staff follows the client company's policies, rules and procedures. They are considered to act as supervisors for the client company. From client expatriates directly monitoring the work of offshore teams reduce information asymmetry between both parties. Expatriation from the client identify and correct possible misalignment problems.

Before I (the expatriate) go there I make an inventory of problems and then we discuss what is going well and what is going wrong. (Interviewee 32, Regional Finance Director, IT)

She (the expatriate) has to monitor whether the Indian people follow the same procedures, the same rules and methodologies. (Interviewee 3, CEO, financial services)

I have review meetings... verifying, going through a list of issues, ... problems which need to be reviewed. (Interviewee 18, Director, Financial Services)

But such direct supervision is often too rigid to address the diversity and complexity of issues faced in offshore outsourcing operations. Expatriates then also play an important role in improving the quality of the communication between the client and offshore members. We 


\section{MANAGEMENT AND ECONOMICS}

found that this is done in a less formal way than the direct supervision, walking around the provider site to informally gather first-hand information about the tasks, activities, progress and issues the local teams face.

When he (the expatriate) had been there for a while, he started to be considered as a native. So he was using, regularly, the coffee machine- the informal contact to build a network. The most important value of having people off-site is the coffee machine. That's where you exchange the Informal knowledge. And if you share the coffee machine long enough-you get to share inarticulate knowledge. And that's what you really need. That's what make the difference between a working project and a non-working project.

Being able to directly observe and talk to offshore members, expatriates sent by the client establish a much more direct channel of communication that improves the exchange of tacit information between the parties (e.g. Choi \& Johanson, 2012). This, in turn, facilitates the identification and correction of misaligned behaviours (see also O'Donnell, 2000).

Next, the presence of expatriates from the client was also reported to be an important way to handover knowledge to the provider through training. Offshore members followed training programs to transfer knowledge about their tasks. This suggests that training programs to transfer adequate knowledge may have a lasting effect on information asymmetry between clients and their offshore providers. The type of knowledge developed through training programs in the form of learning by doing and observations tend to be highly tacit, and in return improve the information asymmetry that exist between both parties.

...they (offshore members) had to tell us (expatriates from client) what they have understood from the process and the application. To make sure that, exactly as you've said it, if you ask them: "did you understood it?", they say yes, but they also have to demonstrate it in a practical way-by teaching us what they have understood. This is an extra over-step we tookup in the process of the knowledge transfer in a good and an efficient way. (Arcelor Mittal)

To train them (offshore members), he(the expatriates) gives them the training, he explains them the pan-European tax, about our processes, about our IT system. It's pretty much teaching everything from A-Z. Of course, in future he will leverage on this experience from someone of his team: so create trainers for the future.

Finally, expatriates are critical in developing and maintaining a relationship with the offshore members, which complements the formal commercial contract that links the client and the provider. Informants shared with us that offshore members typically appreciate that clients send expatriates. They consider this a positive sign of consideration and recognition of the work realized offshore. By their presence and action, the expatriates show the commitment of the client to support the local teams, in exchange of which the client benefits from greater loyalty and motivation of the offshore staff. Specifically, offshore members perceive the presence of expatriates from client as a sign that the client cares about their work and therefore in exchange help foster mutual trust to help the client meet its objectives. Trust does not happen overnight, but rather depend on the social interactions between expatriates and offshore members, which contribute towards the formation of appreciation and recognition. 


\section{MANAGEMENT AND ECONOMICS}

Just be seen there to care-it's quite a work for the motivation of the project.

They work well once you have established a human relationship. So you need to know eachother, you need to spend couple of days together, feel for who the person is, what's important for him, what minds- what doesn't? What's behind the word's he's saying-are they very dryfor that person, are they very strict one, are they a sort of joke or..., so you get to feel for what counts. And then it works. (Dexia)

He knows everybody by his first name, he has been invited by their family. We manage them exactly as our employees (using first name, having the same type of relationship that we have with our own people). In general by the way, this is my personal view with all my contractors. We don't do any difference in the sense if there is a familial event, we can have a drink with them. So we do the same and really, the one people in charge go there with the spirit to spend time with them, with the spirit of knowing them one by one. So the whole reason behind this is that as soon as there is more personal relations, people are happier to work and feel better, and that we have to know who can do what, what they prefer to do. (CIO, Pharmaceutical industry)

However, our results point to a number of pull and push factors that lead clients to increasingly rely on the reverse transfer of personnel from providers to their own premises. Although sending expatriates to providers is useful, over time several clients started facing a number of challenges that made them complement their own expatriates from the client with a reverse transfer of personnel from the offshore providers. First, because of political instability, corruption, or more generally the very different living environment of emerging countries where many providers are located, client often struggle to find candidates for expatriation.

I would not find anybody in my team willing and able to go over there - that's the first core point. (Interviewee 13, IT Manager, Metals)

Second, expatriation candidates from the client may have adequate technical competencies, but face difficulties adjusting to the host environment they are sent to (see also Haslberger et al., 2014), and for that reason fail to exert their adequate role.

We always think that we send an expatriate for technical skills, and we forget the rest. The problem is that it was someone that had technical skills, but no relational skills. And yet, we needed someone who was first of all capable of developing personal links. (Interviewee 27, Delivery services director, Financial services)

Third, expatriates from the client are generally committed to the client's way of doing things. There is thus a risk that they export or even impose their values, rules and norms on offshore employees. This dominant attitude (see also Reiche \& Harzing, 2011) can create tension and conflict in personal relations, and lead to demotivation and low commitment from offshore employees.

Because the solution is not to export your way of working, right? ... If you choose to take in a structure and expertise, then you accept the fact that you're not trying to sort of impose your 


\section{MANAGEMENT AND ECONOMICS}

clumsy way of working on their way of working. (Interviewee 18, Director, Financial Services)

Fourth, when expatriates come back from their assignments, clients need to find them a suitable position in the company. As extant literature has identified (e.g. Yan, Zhu \& Hall, 2007), this is often difficult and brings a lot of uncertainty for the expatriates themselves.

You have to manage him (the expatriate) when he is coming back. This is difficult. You have to find him a seat again. He left the company with a certain position. During the three years you put somebody else but when he is back, where is he going to be? And it is not always obvious that you have a position just when he has finished his contract. (Interviewee 1, CIO, Financial Services)

Next to the challenges linked to clients' expatriation programmes, the fact that the governments of some developing countries put increasing pressure on foreign companies to offer their citizens international careers (Peterson, 2003) also affects the direction of the transfer of personnel.

It is not like as a company, you can decide if you are sending an expatriate over there. They also ask you, from the government: why not an Indian? So every year we need to explain why 'you' (the expatriate) and nobody else. (Interviewee 18, Director, Financial Services)

Finally, we also see that service providers prefer sending their own staff to the clients (see also Manning et al., 2011). More and more thus, they make it a standard practice to send people to the clients for training and relationship building.

The offshore providers offer that automatically when they set up a new contract with us, ... they always come with: 'we send this and this person to you, this one comes back after six months...' They have a whole mechanism and they never ask for our people to come to India. (Interviewee 29, Manager Delivery and Testing, Telecommunication)

Bringing in expatriates from the offshore provider to the client can then become a somewhat forced but also effective solution in managing offshore outsourcing relations. Welcoming in the client company expatriates from the offshore providers create personal ties that help facilitate communication between the teams, not only during the expatriation assignment but also after. Spending time at the client is indeed an effective way to develop personal connections critical to the smooth communication between onshore and offshore teams including after they have returned home.

It is important to have somebody here (expatriate from the provider to the client), to be able to discuss... which is, 6000 kilometres away, not easy, not only because of the time difference, but mainly because of the cultural way of working. He makes sure that the communication remains open and focused on the goal, and is not hindered by misinterpretations. (Interviewee 29, Manager Delivery and Testing, Telecommunication). 


\section{MANAGEMENT AND ECONOMICS}

The expatriate (from the provider) is also psychologically important since the people in Rumania know there is someone who understands them. According to our sources, cultural and communication problems have decreased since he arrived. (Postal \& Courier activities, IP Director \& Resource Management Officer)

He keeps in touch with the people in Rumania to find out their problems shares then with the home office. (Postal \& Courier activities, IP Director \& Resource Management Officer)

It is key, because there are issues, and there are issues all the time. When people know each other... the work afterwards goes much easier. .... The cooperation and solving problems are much easier and smoother. (Interviewee 25, CTO, IT)

Next to help identify and correct possible misalignment problems, the interest of sending offshore staff to the client is to play the role of a linking-pin that help to improve communication and to reduce information asymmetry between the geographical dispersed team.

Second, offshore members are socialized into the client's norms, values and procedures, and progressively adopt them. Being physically present at the client premises, offshore members get to observe and experience first-hand the norms and behaviours expected by the client, and progressively start adopting them.

They need also to understand our company, our culture, our corporate rules, our clients and in our trade it is very hard ...

They (the expatriates from the provider) have to apply our corporate rules, our methodology and the way of thinking as they have learned it here (in Belgium), over there (in India). (Interviewee 25, CTO, IT)

Understanding the business, documents, everything, and absorb the corporate culture. (Interviewee 29, Manager Delivery and Testing, Telecommunication)

We observed that it often takes the form of an intensive training programme whereby expatriation of offshore members are introduced to the specificities of the client context and to the tasks they have to accomplish for the client. The socialization of offshore members in the client raises their identification with the client's norms and values. During the stay at the client, expatriates observe and directly experience the way of working of the client. To help gain acceptance from local colleagues, they start adapting their own behavior. Progressively, these behaviors become part of their identity and continue to influence their behavior after they have returned home. This, again, suggests a lasting effect of expatriation on agency risk. Expatriates from the offshore provider replicate the specificities and the operating procedures of the client in their offshore units.

It allowed an Indian employee to come to Belgium in order to receive training and directives that they would be able to more readily impart on their own countrymen. (Finance Process Owner, Chemicals \& Plastics) 


\section{MANAGEMENT AND ECONOMICS}

But far beyond the formal training on the tasks, the expatriation stay is a unique opportunity to get the onshore and offshore teams to know each other, and start building mutual understanding and trust. The expatriation stay contributes to maintaining and establishing $a$ relationship between the client and the provider's teams. By providing them with an international career opportunity, the client demonstrates that offshore members are valued and can have a future with the company, which enhances their motivation and long-term commitment to the client.

They (offshore members) want their promotion. ... Coming to Belgium is an important step in their career. So the fact that they are able to come (to Belgium) is very important for them. (Interviewee 29, Manager Delivery and Testing, Telecommunication)

It changed everything... I am now not just the Belgian boss, I am now a part of the team, that is very close to them (offshore members). (Design Board)

Our findings point to reduced information asymmetry, to the greater motivation to comply clients' expectations and to empowered trust between clients and offshore providers, as three critical mechanisms that explain how expatriation helps align the behavior of offshore providers with the clients' best interest, and hence reduce agency risk in offshore outsourcing.

\section{Conclusion}

To conclude, the qualitative interview material we collected from 32 client companies located in Belgium offers evidence that the transfer of personnel between clients and their offshore providers enables to mitigate agency risks, and which partly vary in function of the direction of the personnel transfer. By reducing information asymmetry, increasing the motivation to comply, and empowering trust, these different forms of expatriation help align the behavior of offshore providers with the best interest of clients, thereby reducing the agency risk inherent to offshore outsourcing relations.

\section{References}

1. Ang, S., \& Inkpen, A. C. (2008). Cultural intelligence and offshore outsourcing success: A framework of firm- level intercultural capability. Decision Sciences, 39(3), 337358.

2. Björkman, I., Barner-Rasmussen, W., \& Li, L. (2004). Managing knowledge transfer in MNCs: The impact of headquarters control mechanisms. Journal of International Business Studies, 35(5), 443-455.

3. Choi, S. G., \& Johanson, J. (2012). Knowledge translation through expatriates in international knowledge transfer. International Business Review, 21(6), 1148-1157.

4. Contractor, F.J., Kumar, V., Kundu, S.K., \& Pedersen, T., (2010). Reconceptualizing the Firm in a World of Outsourcing and Offshoring: The Organizational and Geographical Relocation of High-Value Company Functions. Journal of Management Studies, 47(8), 14171433.

5. Dibbern, J., Winkler, J., \& Heinzl, A. (2008). Explaining variations in client extra 
costs between software projects offshored to India. MIS quarterly, 32(2), 333-366.

6. Eisenhardt, K. M. (1989). Agency theory: An assessment and review. Academy of management review, 14(1), 57-74.

7. Gooris, J. \& Peeters, C. (2014). Home-host country distance in offshore governance choices. Journal of International Management, 20(1), 73-86.

8. Gooris, J., \& Peeters, C. (2016). Fragmenting global business processes: A protection for proprietary information. Journal of International Business Studies, 47(5), 535-562.

9. Hancox, M., \& Hackney, R. (2000). IT outsourcing frameworks for conceptualizing practice and perception. Information Systems Journal, 10(3), 217-237.

10. Harzing, A. W., Pudelko, M., \& Sebastian Reiche, B. (2016). The bridging role of expatriates and inpatriates in knowledge transfer in multinational corporations. Human Resource Management, 55(4), 679-695.

11. Haslberger, A., Brewster, C., \& Hippler, T. (2014) Managing performance abroad: a new model for understanding expatriate adjustment. London: Routledge.

12. Huber, T. L., Fischer, T. A., Dibbern, J., \& Hirschheim, R. (2013). A process model of complementarity and substitution of contractual and relational governance in IS outsourcing. Journal of Management Information Systems, 30(3), 81-114.

13. Hutzschenreuter, T., Lewin, A. Y., \& Dresel S. (2011). Governance modes for offshoring activities : A comparison of US and German firms. International Business Review, 20, 291-313.

14. Jensen, P. D. Ø. (2009). A learning perspective on the offshoring of advanced services. Journal of international Management, 15(2), 181-193

15. Jensen, P. D. Ø., \& Pedersen, T., (2011). The economic geography of offshoring: the fit between activities and local context. Journal of Management Studies, 48, 352-72.

16. Koh, C., Ang, S., \& Straub, D. W. (2004). IT outsourcing success: A psychological contract perspective. Information Systems Research, 15(4), 356-373.

17. Kshetri, N. (2007). Institutional factors affecting offshore business process and information technology outsourcing. Journal of International Management, 13(1), 38-56.

18. Kumar, K., Van Fenema, P. C., \& Von Glinow, M. A. (2009). Offshoring and the global distribution of work: Implications for task interdependence theory and practice. Journal of International Business Studies, 40(4), 642-667.

19. Levina, N., \& Vaast, E. (2008). Innovating or doing as told? Status differences and overlapping boundaries in offshore collaboration. MIS quarterly, 32(2), 307-332.

20. Lewin A.Y., Massini S., \& Peeters C. (2009). Why are companies offshoring innovation? The emerging global race for talent. Journal of International Business Studies, 40 (6), 901-925.

21. Lewin, A. Y. \& Peeters, C. (2006). Offshoring work: Business hype or the onset of fundamental transformation. Long Range Planning, 39(3), 221-239.

22. Li, Y., Xie, E., Teo, H. H., \& Peng, M. W. (2010). Formal control and social control in domestic and international buyer-supplier relationships. Journal of Operations Management, 28(4), 333-344.

23. Manning S., Lewin A.Y. \& Schuerch M. (2011). The stability of offshore outsourcing relationships: The role of relation specificity and client control. Management International Review, 51 (3), 381-406.

24. O'Donnell, S. W. (2000). Managing foreign subsidiaries: agents of headquarters, or an interdependent network? Strategic Management Journal, 21(5), 525-548. 


\section{$3^{\text {rd }}$ International Conference On Research In}

\section{MANAGEMENT AND ECONOMICS}

25. Peeters, C., Dehon, C., \& Garcia-Prieto, P. (2015). The attention stimulus of cultural differences in global services sourcing. Journal of International Business Studies, 46(2), 241251.

26. Peterson, R. B. (2003). The use of expatriates and inpatriates in Central and Eastern Europe since the wall came down. Journal of World Business, 38(1), 55-69.

27. Poppo, L., \& Zenger, T. (2002). Do formal contracts and relational governance function as substitutes or complements? Strategic Management Journal, 23(8), 707-725.

28. Reiche, S., \& Harzing, A.-W. (2011). International assignments. In A.-W. Harzing \& A. Pinnington, (Eds.), International Human Resource Management: 185-226..Third ed. London: Sage Publications.

29. Roth, K., \& O'Donnell, S. (1996). Foreign subsidiary compensation strategy: An agency theory perspective. Academy of management Journal, 39(3), 678-703.

30. Sidhu, J. S., \& Volberda, H. W. (2011). Coordination of globally distributed teams: A co-evolution perspective on offshoring. International Business Review, 20(3), 278-290.

31. Stringfellow, A., Teagarden, M.B. \& Nie, W. (2008). Invisible costs in offshoring services work. Journal of Operations Management, 26(2), 164-179.

32. Welch, C., Marschan-Piekkari, R., Penttinen, H., \& Tahvanainen, M.(2002). Corporate elites as informants in qualitative international business research. International Business Review, 11, 611-628.

33. Yan, A., Zhu, G., \& Hall, D. T. (2002). International assignments for career building: A model of agency relationships and psychological contracts. Academy of Management Review, 27(3), 373-391. 